[Agr. Biol. Chem., Vol. 35, No. 8, p. 1173 1179, 1971]

\title{
Studies on Oxalacetate Carboxylyase of Pig Heart Muscle ${ }^{\dagger}$
}

\author{
Part II. Distinction of Oxalacetate Carboxylyase from Other \\ Oxalacetate Decarboxylating Enzymes and Some \\ Considerations on the Physiological \\ Significance of the Enzyme
}

\author{
By Takio Morinaga and Masaharu ShIRAKAWA \\ Laboratory of Biochemistry, Faculty of Domestic Science, \\ Fukuoka Woman's University \\ Received October 3, 1970
}

\begin{abstract}
The existence of oxalacetate carboxylase (OAC-lyase), distinct from other oxalacetate decarboxylating enzymes, was concluded by the following facts: (1) the enzyme action was not effected by ATP, ADP, acetyl CoA and avidin and was not stimulated by LTP, different from pyruvate carboxylase and phosphoenol pyruvate carboxykinase; (2) although an appreciable amount of malic enzyme activity was found in the crude extract of pig heart muscle, the purified preparation of OAC-lyase was completely free from this activity; (3) OAC-lyase activity was unaffected by $\mathrm{NADP}^{+}$and L-cysteine, different from the decarboxylating activity of malic enzyme.

The reversibility of OAC-lyase reaction was studied by a tracer technique, and it was found that the reaction was practically irreversible.

As regards the physiological significance of OAC-lyase, a preliminary experiment on the transcarboxylation between oxalacetate and acetyl CoA by OAC-lyase were unsuccessful.
\end{abstract}

In the preceding paper the purification and enzymic properties of OAC-lyase(EC 4.1.1.3) from pig heart muscle have been described. The enzyme was so unstable that it was difficult to purify above 50 -fold over the crude extract.

The enzyme was activated by some bivalent metal ions, among which $\mathrm{Mn}^{2+}$ was the most effective and was independent of redox and ergonic nucleotides and avidin. Results ob-

t Part I of the series: T. Morinaga and M. Shirakawa, Agr. Biol. Chem., 35, 1166 (1971).

Abbreviations. OAC-lyase: oxalacetate carboxylyase, OA: oxalacetate, PEP: phosphoenol pyruvate, MDH: malate dehydrogenase, $\mathrm{LDH}$ : lactate dehydrogenase, BSA: bovine serum albumin, CMC: CM-cellulose, DEAEC: DEAE-cellulose. tained were in accord with those of the cod fish enzyme as reported by Schmitt et al. ${ }^{11}$ and Kosicki. ${ }^{21}$

As pointed out previously, there remained some obscurities caused by the fact that other OA-decarboxylating enzymes, especially malic enzyme(EC 1.1.1.40), contributed to OAClyase activity. Although it is possible to distinguish OAC-lyase from pyruvate carboxylase (EC 6.4.1.1) and PEP-carboxykinase(EG 4.1.1. 32) under the suitable conditions of activity measurements, malic enzyme might be confused with OAC-lyase because of its ability to decarboxylate OA under the similar con-

1) A. Schmitt, I. Bottke and G. Siebert, Z. physiol. Chem., 347, 18 (1966).

2) G. W. Kosicki, Biochemistry, 7, 4299 (1968). 
ditions, even in the absence of $\mathrm{NADP}^{+3,41}$

The existence of OAC-layse in mammalian tissues, whose physiological function is hard to understand in the light of present knowledge of general metabolism, is of considerable interest. In this regard, a preliminary study was carried out on the transcarboxylation between $\mathrm{OA}$ and acetyl CoA by this enzyme, like the case of OA-methylmalonyl CoA transcarboxylase (EG 2.1.3.1) in Propionibacterium by Swick and Wood. ${ }^{5 !}$

In the present paper we will describe the distinction of OAC-lyase in pig heart muscle from other OA-decarboxylating enzymes, reversibility of the enzyme action and possibility of the transcarboxylation by OAC-lyase.

\section{METHODS}

Enzyme solutions. Preparation of pig heart OAClyase was described in the preceding paper. When rat heart and liver were employed, crude extracts were prepared as follows: slices of rat heart and liver were suspended in an equal volume of $20 \mathrm{~mm}$ Tris$\mathrm{HCl}$ buffer ( $\mathrm{pH} 8.0$ ) containing $5 \mathrm{mM}$ mercaptoethanol and $0.25 \mathrm{M}$ sucrose, and homogenized in a glass homogenizer. Homogenates were centrifuged $(35,000 \mathrm{rpm}$, $40 \mathrm{~min}$ ) and the supernatant was collected.

Enzyme activities. OAC-lyase activity was measured by the methods reported previously. Malic enzyme activity was assayed spectrophotometrically according to the method of Hsu and Lardy.6) The reaction mixture consisted of $100 \mu$ moles of Tris- $\mathrm{HCl}$ buffer ( $\mathrm{pH} 7.4$ ), $0.5 \mu$ mole of L-malate, $1 \mu$ mole of $\mathrm{NADP}^{+}, 25 \mu$ moles of $\mathrm{MgSO}_{4}, 1 \mathrm{mg}$ of BSA, $0.1 \mathrm{ml}$ of enzyme solution and water to make a final volume of $1.0 \mathrm{ml}$. L-Malate solution was added to start the reaction and the rate of formation of $\mathrm{NADPH}$ was measured spectrophotometrically at $340 \mathrm{~m} \mu$ using a

3) S. Ochoa, A. H. Mehler and A. Kornberg, $J$. Biol. Chem., 174, 979 (1948).

4) W.J. Ruther and H. A. Lardy, ibid., 233, 374 (1958).

5) R. W. Swick and H. G. Wood, Proc. Natl. Acad. Sci. U.S., 46, 28 (1960).

6) R. Y. Hsu and H. A. Lardy, J. Biol. Chem., 242, 520 (1967).
Gilford spectrophotometer (Model 200). One unit of enzyme activity was defined as the amount of enzyme which catalyzes the formation of $1 \mu$ mole of NADPH per min.

Acetyl CoA carboxylase activity was measured by the method of Yugari et al.71 The reaction mixture $(0.17 \mathrm{ml})$ contained $30 \mu$ moles of imidazole hydrochloride buffer ( $\mathrm{pH} 6.5$ ), $1 \mu$ mole of mercaptoethanol, $0.3 \mu \mathrm{mole}$ of potassium citrate, $0.1 \mathrm{ml}$ of enzyme solution and an adequate volume of water. After incubation of the mixture at $30^{\circ} \mathrm{C}$ for $60 \mathrm{~min}, 0.14$ $\mu$ mole of acetyl $\mathrm{CoA}, 1 \mu$ mole of $\mathrm{MnCl}_{2}, 2 \mu$ moles of ATP, $15 \mu$ moles of $\mathrm{NaHCO}_{3}, 1 \mu \mathrm{Ci}$ of $\mathrm{NaH}^{14} \mathrm{CO}_{3}$ $\left(4.9 \times 10^{5} \mathrm{cpm}\right)$ and an adequate volume of water to make a final volume of $0.3 \mathrm{ml}$ were added. After further $10 \mathrm{~min}$ incubation at $30^{\circ} \mathrm{C}$, the reaction was stopped by the addition of 7 to $8 \mathrm{mg}$ of Dowex 50 $-\mathrm{H}^{+}$until the $\mathrm{pH}$ of the mixture fell to 2.0. Excess $\mathrm{CO}_{2}$ generated was trapped in $20 \% \mathrm{KOH}$ by aeration and then insoluble matter was centrifuged off. A 0.1 $\mathrm{ml}$ aliquot of the supernatant solution was added to the tracer solvent* and was counted for the radioactivity.

OA-acetyl CoA transcarboxylase activity was tested through the identification of malonyl-14 $\mathrm{C}$ CoA formed by the enzymic transcarboxylation between acetyl $\mathrm{CoA}$ and $\mathrm{OA}-\mathrm{U}-{ }^{14} \mathrm{C}$, which had been prepared by enzymic dehydrogenation of L-malate-U-14C. A $0.2 \mathrm{ml}$ aliquot of the reaction mixture containing $0.05 \mathrm{ml}$ of Medium $\mathrm{A}^{* *}, 0.5 \mu$ mole of pyruvate, 3.6 units of $\mathrm{LDH}, 3.5$ units of $\mathrm{MDH}, 0.1 \mathrm{ml}$ of enzyme solution and water was incubated at $30^{\circ} \mathrm{C}$ for $30 \mathrm{~min}$. To the reaction mixture containing $\mathrm{OA}-\mathrm{U}-{ }^{14} \mathrm{C}$ formed were added $0.1 \mathrm{ml}$ of Medium $\mathrm{B}^{* * *}$ and $0.1 \mu \mathrm{mole}$ acetyl CoA, and the mixture was incubated again for $30 \mathrm{~min}$ at $30^{\circ} \mathrm{C}$. The reaction was stopped by adding $0.5 \mathrm{ml}$ of $2 \mathrm{~N} \mathrm{HCl}$ and the reaction mixture was centrifuged. 2,4-Dinitrophenyl hydrazine $(0.01$ $\mathrm{ml}, 20 \mathrm{~mm}$ ) was added to the supernatant solution in order to trap ketoacids and the hydrazone formed

7) Y. Yugari, T. Matsuda, T. Mise and M. Suda, Proc. Symp. Chem. Physiol. Pathol., 3, 43 (1963).

* The tracer solvent: toluene-tritonX100(2:1).

** Medium A contained $2 \mu$ moles of Tris- $\mathrm{HCl}$ buffer ( $\mathrm{pH}$ 8.4), $0.1 \mu$ mole of L-malate, $0.2 \mu \mathrm{Ci}$ of $\mathrm{L}$-malate-U-14C and $0.1 \mu$ mole of $\mathrm{NAD}^{+}$in a final volume of $0.05 \mathrm{ml}$.

*** Medium B $(0.1 \mathrm{ml})$ contained $40 \mu$ moles of imidazole- $\mathrm{HCl}$ buffer ( $\mathrm{pH} 6.5$ ), $1 \mu$ mole of mercaptoethanol, $2 \mu$ moles of ATP and $1 \mu$ mole of $\mathrm{MnCl}_{2}$. 
was removed by extraction with ethyl acetate. A small amount of charcoal was then added to the solution and the mixture was centrifuged. The precipitate was washed three times with $1 \mathrm{ml}$ of $1 \mathrm{~N} \mathrm{HCl}$ and then treated with $1 \mathrm{ml}$ of $4 \mathrm{~N}$ ammonium hydroxide. The eluate obtained by centrifugation was evaporated to dryness. The residue was dissolved in $5 \mathrm{ml}$ of the tracer solvent and its radioactivity was measured. The formation of $\mathrm{OA}-\mathrm{U}-{ }^{14} \mathrm{C}$ was determined preliminarily by measuring radioactivities of 2,4-dinitrophenyl hydrazone formed in the reaction mixture. It was found that $21 \%$ of the initial radioactivity was fixed in $\mathrm{OA}$ under the above conditions.

\section{Reversibility of $O A C$-lyase reaction}

a) Identification of malic acid by paper chromatography. $\mathrm{OA}$ formed from pyruvate by OAC-Iyase was reduced to malic acid in the presence of $M D H$ and NADH, and malic acid was detected chromatographycally. The reaction mixture containing 1.5 mmoles of TrisHCl buffer ( $\mathrm{pH} 7.4$ ), $150 \mu$ moles of pyruvate, 37.5 $\mu$ moles of ATP, $12 \mu$ moles of NADH, $12 \mu$ moles of $\mathrm{MnCl}_{2}, 300 \mu$ moles of $\mathrm{NaHCO}_{3}, 1.8 \mu$ moles of acetyl CoA, 10 units of $\mathrm{MDH}$ and OAC-lyase in a final volume of $15 \mathrm{ml}$ was incubated at $30^{\circ} \mathrm{C}$ for $30 \mathrm{~min}$. The reaction was stopped by the addition of an equal volume of ethanol and the mixture was heated for $5 \mathrm{~min}$ in a boiling water bath. After the solution had been cooled, coagulated protein was centrifuged off. The supernatant solution was evaporated to dryness. The residue was extracted three times with $80 \%$ methanol and the extracts were combined and dried up. The residue was dissolved in a minimal amount of water and applied to paper chromatography using a solvent system, $n$-propanol-ammonia (30\%)-water $(60: 30: 10, \mathrm{v} / \mathrm{v})$. Organic acids were detected by spraying bromphenol blue solution.

b) ${ }^{14} \mathrm{CO}_{2}$-fixation by $O A C$-lyase. The reaction mixture (see Table III) was incubated at $30^{\circ} \mathrm{C}$ for $30 \mathrm{~min}$ and $1 \mathrm{ml}$ of $1 \mathrm{~N} \mathrm{HCl}$ was added to stop the reaction. After excess $\mathrm{CO}_{2}$ had been removed by aeration, 1 $\mathrm{ml}$ of the solution was added to $5 \mathrm{ml}$ of the tracer solvent and the radioactivity was measured with a liquid scintillation counter (Beckman LS 250).

Protein contents. Protein was estimated by FolinCiocalteu's method.8) BSA was used as the standard.

8) O. Folin and V. Ciocalteu, J. Biol. Chem., 73, 629 (1927).

\section{RESULTS}

It was found that $\mathrm{OAC}$-lyase activity was practically indifferent to ADP, ATP, NAD ${ }^{+}$, NADH, NADP ${ }^{+}$and acetyl CoA (Table I). ITP which is required for PEP-carboxykinase activity $^{9,101}$ exhibited a weak inhibitory effect.

The reversibility of enzymic decarboxylation of OA was investigated. OA which might be formed from pyruvate and $\mathrm{NaHCO}_{3}$ was attempted to be identified by the following three methods. (a) Changes of absorbancy at $255 \mathrm{~m} \mu^{1\}}$ which is attributable to OA were measured in the reverse enzyme reaction. Results are illustrated in Table II. Enzymic synthesis of OA from pyruvate was not recognized. (b) It was attempted to identify malic acid which might be derived from OA in the presence of $\mathrm{MDH}$ and NADH. As shown in Fig. 1, malic acid was not detected. (c) A tracer technique was employed finally. Pyruvate, $\mathrm{NaH}^{14} \mathrm{CO}_{3}$ and some cofactors were incubated with the enzyme and after removement of remaining $\mathrm{NaH}^{14} \mathrm{CO}_{3},{ }^{14} \mathrm{C}$-activity attributable to $\mathrm{OA}-{ }^{14} \mathrm{G}$ in the solution was measured. As illustrated in Table III and IV, net incorporation was not detected. It was concluded that the decarboxylation of

TABle I. EFFect of SOME Nucleotides Activities were assayed manometrically.

\begin{tabular}{lcc}
\hline Addition & $\begin{array}{c}\text { Final concentration } \\
\mathrm{mM}\end{array}$ & $\begin{array}{c}\text { Relative } \\
\text { activity }\end{array}$ \\
\hline None & & 100 \\
ATP & 0.17 & 117 \\
ADP & 0.10 & 107 \\
ITP & 0.30 & 61 \\
NAD & 0.15 & 99 \\
NADH & 0.15 & 109 \\
NADP+ & 1.00 & 103 \\
Acetyl Co A & 0.12 & 103 \\
\hline
\end{tabular}

9) M. F. Utter, K. Kurahashi and I. A. Rose, J. Biol. Chem., 207, 803 (1954).

10) H. C. Chang and M. D. Lane, ibid., 241, 2413 (1966). 
TABLE II. REVERSIBILITY OF OAC-LYASE REACTION (A)

Complete system contained, in $3.0 \mathrm{ml}, 150 \mu$ moles Tris-HCl buffer (pH 7.4), $0.25 \mu$ mole $\mathrm{MnCl}_{2}, 7.5 \mu$ moles pyruvate, $0.047 \mu$ mole ATP, $15 \mu$ moles $\mathrm{NaHCO}_{3}$, $0.08 \mu$ mole acetyl Co $\mathrm{A}$ and $0.1 \mathrm{ml}$ OAC-lyase.

\begin{tabular}{lcc}
\hline \multirow{2}{*}{ Reaction system } & \multicolumn{2}{c}{ O.D. $(255 \mathrm{~m} \mu)$} \\
\cline { 2 - 3 } & Initial & After $10 \mathrm{~min}$ \\
\hline Complete system & 1.000 & 1.000 \\
$\quad$ Acetyl Co A omitted & 0.590 & 0.590 \\
Acetyl Co A and OAC-lyase & & \\
$\quad$ omitted & 0.550 & 0.550 \\
OAC-lyase only & 0.035 & 0.035 \\
Acetyl Co A only & 0.485 & 0.485 \\
OAC-lyase+Acetyl Co A & 0.520 & 0.520 \\
\hline
\end{tabular}

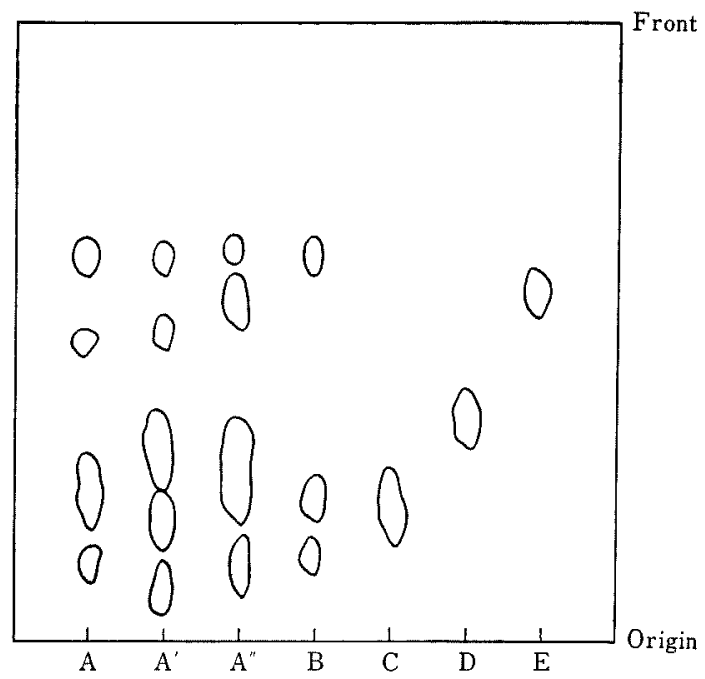

FIG. 1. Paperchromatogram for the Detection of Malate.

Complete reaction system was described in "Methods.",

Solvent system: $n$-propanol-ammonia (300)-water $(60: 30: 10 v / v)$. A: Complete system. A': Complete system $+\mathrm{D}, \mathrm{L}$-malate. $\mathrm{A}^{\prime \prime}$ : Complete system + D,L-lactate. B: Pyruvate, ATP and acetyl CoA were omitted from complete system. C: Pyruvate (only). D: Malate (only). E: Lactate (only).
OA by OAC-lyase was practically irreversible. Malic enzyme activity was measured at each stage in the purification of OAC-lyase (Table V). Although the crude extract contained considerable amounts of malic enzyme,

\section{TABLE III. REVERSIBILITY OF OAC-LYASE REACTION (B)}

Reaction system contained, in $0.1 \mathrm{ml}, 10 \mu$ moles Tris HCl buffer ( $\mathrm{pH}$ 7.4), $1 \mu$ mole pyruvate, $1 \mu$ mole $\mathrm{MgCl}_{2}, 3 \mu$ moles $\mathrm{NaHCO}_{3}, 0.06 \mu \mathrm{Ci} \mathrm{NaH}{ }^{14} \mathrm{CO}_{3}, 0.25$ $\mu$ mole ATP, $0.46 \mu$ mole acetyl Co A and $0.05 \mathrm{ml}$ enzyme solution.

\begin{tabular}{cc}
$\begin{array}{c}\text { Enzyme concentration } \\
\mathrm{mg} / \mathrm{ml}\end{array}$ & $\begin{array}{c}{ }^{14} \mathrm{CO}_{2} \text { fixed } \\
\text { counts/min }\end{array}$ \\
\hline 0.1 & 7.6 \\
1.0 & 9.5 \\
2.0 & 4.0 \\
5.0 & 2.5 \\
10.0 & 7.5 \\
\hline
\end{tabular}

TABle IV. ReVersibility of OAG-Lyase REACTION (C)

Reaction systems are the same as described in Table III.

\begin{tabular}{lc}
\hline Reaction system & $\begin{array}{c}{ }^{14} \mathrm{CO}_{2} \text { fixed } \\
\text { counts/min }\end{array}$ \\
\hline Complete & 13.0 \\
Acetyl Co A omitted & 13.5 \\
ATP omitted & 21.5 \\
\hline
\end{tabular}

Table V. Malic Enzyme ACtivity of Different OAC-Lyase Preparations

\begin{tabular}{lccc}
\hline Purification stage & \multicolumn{2}{c}{ Activity } & Activity \\
\cline { 2 - 4 } & $\begin{array}{c}\text { OAG- } \\
\text { lyase } \\
\text { units/ml }\end{array}$ & $\begin{array}{c}\text { Malic } \\
\text { enzyme } \\
\text { units/ml }\end{array}$ & $\begin{array}{c}\text { Malic/ } \\
\text { OAC }\end{array}$ \\
\hline Crude extract & 0.36 & 0.04 & 0.11 \\
After salting-out & 1.14 & 0.18 & 0.16 \\
After CMC-treatment & 0.30 & 0.01 & 0.03 \\
After DEAEC-treatment & 0.16 & 0 & 0 \\
After Sephadex-treatment & 0.22 & 0 & 0
\end{tabular}

a) As regards the purification stage, see the preceding report. 
the activity ratio of malic enzyme to OAClyase at each stage decreased markedly along with the progress of purification, especially at the stage of CMC-column chromatography. Malic enzyme adsorbed on CMC-column was not eluted at the same conditions as the case of OAC-lyase, but was eluted at $\mathrm{pH} 9.0$ with a good yield (Table VI). Typical elution patterns of malic enzyme and OAC-lyase from Sephadex G-200 column are shown in Fig. 2. OAC-lyase and malic enzyme were eluted in nearly the same fractions, suggesting that both enzymes had approximately the same order of molecular size.

Acetyl CoA carboxylase activity in OAC-

\section{TABLe VI. ELUtion of Malic Enzyme FROM CMC-COLUMN}

One $\mathrm{g}$ of wet CMC, which had been pretreated with $5 \mathrm{mM}$ phosphate buffer $(\mathrm{pH} 6.0$ ), was added to $5 \mathrm{ml}$ of buffered enzyme solution ( $4 \mathrm{mM}$ phosphate, $\mathrm{pH}$ 6.0) and the mixture was stirred for $10 \mathrm{~min}$. After centrifugation, the precipitate was washed by $5 \mathrm{ml}$ of $5 \mathrm{mM}$ phosphate buffer $(\mathrm{pH} 6.0$ ), and then malic enzyme adsorbed was eluted by $5 \mathrm{ml}$ of $1 \mathrm{M}$ tris-HCl buffer ( $\mathrm{pH} 6.0,7.4$ or 9.0). Malic enzyme activity of each eluate was measured spectrophotometrically.

\begin{tabular}{cc}
\hline $\mathrm{pH}$ of elution buffer & Relative activitya) \\
\hline 6.0 & 54 \\
7.4 & 67 \\
9.0 & 98 \\
\hline
\end{tabular}

a) The activity of the initial enzyme solution was taken as standard (100).

Table VII. ACETyl Co A Carboxylase ACtivity of the Purified Preparation of OAC-Lyase

\begin{tabular}{lc}
\hline \multicolumn{1}{c}{ Enzyme preparation } & $\begin{array}{c}{ }^{14} \mathrm{CO}_{2} \text { fixed } \\
\text { counts/min }\end{array}$ \\
\hline $\begin{array}{l}\text { OAC-lyase preparation of pig } \\
\text { heart muscle }\end{array}$ & 21 \\
Rat heart extract & 304 \\
Rat liver extract & 14,449 \\
\hline
\end{tabular}

lyase preparations were measured. Experiments were carried out in order to avoid any confusion by the enzyme contaminated for the detection of enzymic transcarboxylation between OA and acetyl CoA. As shown in Table VII, the purified OAC-lyase preparation of pig heart muscle contained little amount of acetyl CoA carboxylase, but a little more was found in rat heart extract and much more in rat liver extract.

OA-acetyl CoA transcarboxylase activity of pig heart OAG-lyase was studied. Transcarboxylase activity was measured by the determination of malonyl $-{ }^{14} \mathrm{C}$ CoA formed by the enzymic transcarboxylation between OA-U${ }^{14} \mathrm{C}$ and acetyl CoA. OA-U $-{ }^{14} \mathrm{C}$ was prepared by the enzymic dehydrogenation of L-malate$\mathrm{U}^{14} \mathrm{C}$ in the presence of $\mathrm{MDH}$ and $\mathrm{NAD}^{+}$ with about $20 \%$ yield. As described above, OAC-lyase preparations contained little amount of acetyl CoA carboxylase and its contribution to the measurements was negligible. To avoid further contributions of

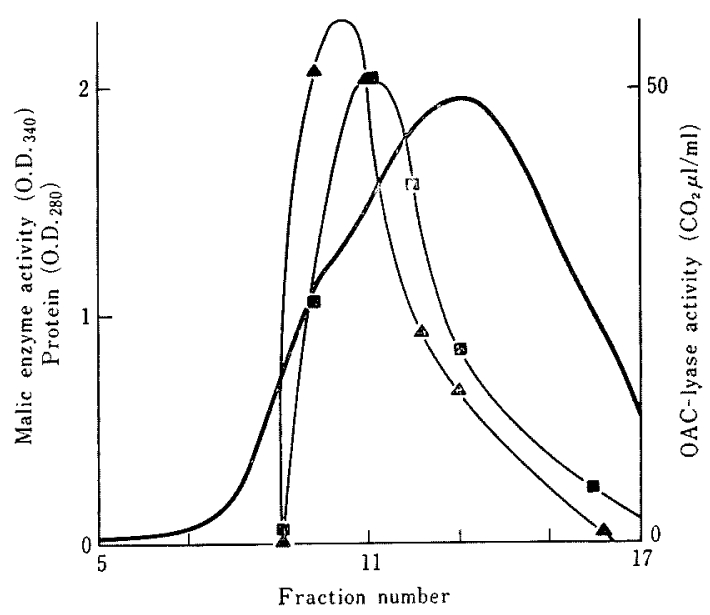

FIG. 2. Gel Filtration on Sephadex G-200.

Column size: $1.5 \times 52 \mathrm{~cm}$. Enzyme solution applied: $5 \mathrm{ml}$. Elution buffer: $50 \mathrm{~mm}$ phosphate buffer (pH 6.0). Fraction: $5 \mathrm{ml} /$ tube. Flow rate: $20 \mathrm{ml} / \mathrm{hr}$.

-: Protein,

Malic enzyme

A: OACmlyase. 
Table VIII. Transcarboxylation between OA AND ACETYL Co A

Radioactivity of L-malate-U-14 C used was $4.41 \times 10^{5}$ counts/min in each test.

\begin{tabular}{lcc}
\hline Enzyme preparation & \multicolumn{2}{c}{${ }^{14} \mathrm{CO}_{2}$ fixed } \\
\cline { 2 - 3 } & $\begin{array}{c}\text { In the } \\
\text { presence } \\
\text { of avidin } \\
\text { counts/min }\end{array}$ & $\begin{array}{c}\text { In the } \\
\text { absence } \\
\text { of avidin } \\
\text { counts/min }\end{array}$ \\
\hline $\begin{array}{c}\text { OAC-lyase preparation from } \\
\text { pig heart muscle }\end{array}$ & 292 & 25 \\
Rat heart extract & 361 & - \\
Rat liver extract & 493 & 0 \\
\hline
\end{tabular}

biotin dependent enzymes, ${ }^{11 \sim 16)}$ experiments were carried out in the presence or absence of avidin. As shown in Table VIII, the transcarboxylation by OAC-lyase was practically not observed in the presence of avidin.

\section{DISCUSSION}

The corelation of four kinds of OA-decarboxylating enzymes are schematically illustrated in Fig. 3, together with their distribution in cell fractions. Reactions (A), (B), (C) and (D) are catalyzed by pyruvate carboxylase, OAC-lyase, malic enzyme and PEPcarboxykinase respectively.

OAG-lyase of pig heart muscle was activated by $\mathrm{Mn}^{2+}$ but its activity was not affected by ADP, ATP, acetyl CoA or avidin, different from OA-decarboxylating action of pyruvate

11) S. J. Wakil, E. B. Titchener and K. M. Gibson, Biochim. Biophys. Acta, 29, 225 (1958).

12) D. B. Martin and P. R. Vagelos, J. Biol. Chem., 237, 1787 (1962).

13) D. B. Northrop and H. G. Wood, ibid., 244, 5801 (1969).

14) M. Flavin and S. Ochoa, ibid., 229, 965 (1957).

15) A. Tietz and S. Ochoa, ibid., 234, 1394 (1959).

16) B. K. Bachhawat, W. G. Robinson and M.J. Coon, ibid., 219, 539 (1956).

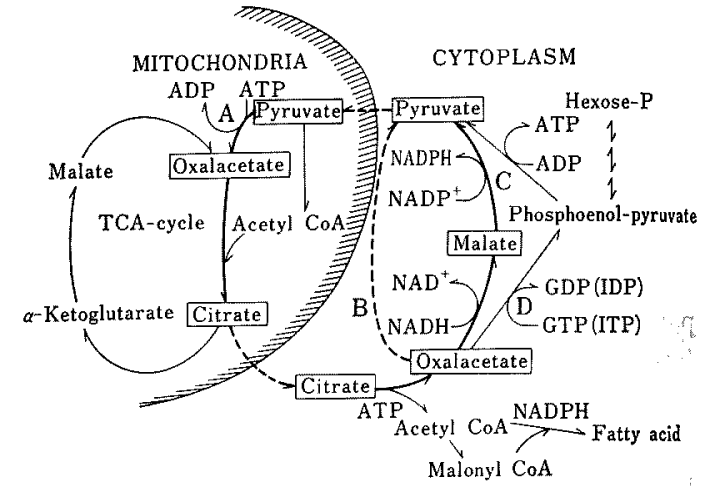

FIG. 3. Pyruvate Gycle and OA-Decarboxylating Enzymes.

A: Pyruvate carboxylase, B: OAC-lyase, C: Malic enzyme, D: PEP-carboxykinase.

The framed compounds are members of the pyruvate cycle.

carboxylase. ${ }^{17,18)}$ OAC-lyase was not activated by ITP, which is required for OA-decarboxylating action of PEP-carboxykinase. ${ }^{9,101}$ The same had been observed in the case of OAClyase in cod fish ${ }^{11}$ and rat liver. ${ }^{191}$

It was known that malic enzyme was bifunctional, namely it decarboxylates not only L-malate oxidatively but also $\mathrm{OA}$ non-oxidatively. ${ }^{3 \prime}$ The possibility that OAC-lyase activity might be due to malic enzyme was excluded by following facts: (1) the optimal $\mathrm{pH}$ of OAC-lyase was 7.0, which was apparently higher than that of OA-decarboxylating activity of malic enzyme (4.5); ${ }^{203}$ (2) the activity of OAC-lyase was independent of $\mathrm{NADP}^{+}$and L-cysteine which stimulate malic enzyme activity, ${ }^{4}$ and also independent of L-malate which is an inhibitor of malic enzyme; (3) the activity ratio of malic

17) M. F. Utter and D. B. Keech, J. Biol. Chem, 238, 2603, 2609 (1963).

18) M. C. Scrutton and M. F. Utter, ibid., 240, 1 (1965).

19) L. M. Corwin, ibid., 234, 1338 (1959).

20) A. H. Mehler, A. Kornberg, S. Grisolia and S. Ochoa, ibid., 174, 961 (1948). 
enzyme to OAC-lyase decreased markedly through the purification processes, especially in the step of CMC-column chromatography.

It was assumed from the results of gel filtration by Sephadex G-200 that the molecular size of OAC-lyase was approximately the same with that of malic enzyme (Fig. 2) and hence the possibility that OAC-lyase might be generated by dissociation of malic enzyme to its subunits was practically excluded.

Reversibility of the reaction catalyzed by OAC-lyase was investigated by measurements of ${ }^{14} \mathrm{C}$-incorporation into $\mathrm{OA}$ from ${ }^{14} \mathrm{C}$-labelled bicarbonate. As the results, net incorporation was not observed (Table II, III and IV) and it was concluded that the decarboxylating reaction of $\mathrm{OA}$ by OAC-lyase was practically irreversible.

Although pyruvate carboxylase plays an important metabolic role in the synthetic reaction of $\mathrm{OA}^{17,211}$ (see Fig. 3), the physiological function of OAC-lyase should be found rather in the decarboxylating reaction of $\mathrm{OA}$, but little has been known yet in this regard. We tentatively assumed the existence of a

21) M.F. Utter, D. B. Keech and M. C. Scrutton, Advances in Enzyme Regulation, 2, 49 (1964). transcarboxylation reaction between $\mathrm{OA}$ and acetyl CoA by OAC-lyase, referring to OAmethylmalonyl CoA transcarboxylase(EG 2.1. 3.1) which had been found in Propionibacterium by Swick and Wood. ${ }^{51}{ }^{14} \mathrm{C}$-Exchange between $\mathrm{OA}-\mathrm{U}-{ }^{14} \mathrm{C}$ and malonyl $\mathrm{CoA}$ was studied without success.

The metabolic function of OAC-lyase remains still in vague. According to the pyruvate cycle proposed by $\mathrm{Katz}$ et al. ${ }^{22 !} \mathrm{OA}$ is reduced to malate with the consumption of $\mathrm{NADH}$ and malate formed is decarboxylated to pyruvate with the formation of NADPH, which is required for lipogenesis. ${ }^{2,241}$ The pathway from OA to pyruvate by OAC-lyase will be of no use for organisms only except the case in which NADPH is supplied in excess by the pentose cycle and elsewhere.

Acknowledgements. The authors wish to express their thanks to Prof. M. Suda and Assistant Prof. $Y$. Yugari, Institute for Protein Research of Osaka University for their valuable advices through this work.

22) R. Rognstad and J. Katz, Proc. Natl. Acad. Sci. U.S., 55, 1148 (1966).

23) J. Katz, B. R. Landau and G. E. Bartsch, $J$. Biol. Chem., 241, 727 (1966).

24) J. P. Flatt and E. G. Ball, ibid., 239, 675 (1964). 